\title{
Stress-strain state investigation of the "YASUNI" shell by bionic architecture methods based on numerical modeling
}

\author{
Olga O. Alyoshina ${ }^{1}$, David Cajamarca Zuniga ${ }^{2 *}$ \\ ${ }^{1}$ Peoples' Friendship University of Russia (RUDN University) \\ 6 Mikluho-Maklaya St., Moscow, 117198, Russian Federation \\ ${ }^{2}$ Catholic University of Cuenca, Ecuador \\ 288 Av. Don Bosco, Cuenca, 0101114, Ecuador \\ *Corresponding author
}

(received: May 04, 2018; accepted: July 26, 2018)

\begin{abstract}
It is hard to imagine architecture and construction without large-span shells of various applications and taking into consideration the requests of architects, the new achievements in numeral modeling of the surfaces and introduction of new groups of tailored surfaces, the appearance of new forms and types of thin-walled shell structures of this kind is inevitable. The bionic method of solving these tasks pushes the boundaries of these opportunities. The subject being studied is the stress strain state of new uncanonical shell "YASUNI", designed of monolithic reinforced concrete with the use of modern finite element analysis settlement system. The form of the shell is built on the basis of images of the Ecuadorian flora. The form of the shell imitates a leaf of a flower laying on the lay of the land. The triangle finite-element mesh is created with a harmonic fusion of lily and daisy in a single structure. The shell is designed as a solid-cast one, made of different classes of reinforced concrete (B25, B30, B35) with thickness from $\delta=5 \mathrm{~cm}$ to $\delta=10 \mathrm{~cm}$ with a step $1 \mathrm{~cm}$ without contouring beams. The structure is subjected to self-weight. The article introduces the first results of the research of stress strain state of the shell "YASUNI". The authors continue the research of the work this shell with different geometrical parameters, the boundary conditions with the addition of contour elements. Due to the computing complex SCAD OFFICE, precision of which is enough to perform calculations it is possible to reach the most advantageous technical-and-economic indexes of the researched uncanonical shell.
\end{abstract}

Keywords: shell of uncanonical form, bionic architecture, finite element method, triangle finite-element mesh, stressstrain state, monolithic reinforced concrete structure, computer system SCAD Office

\section{Introduction}

It is hard to imagine architecture and construction without large-span shells of various applications [1] and taking into consideration the requests of architects, the new achievements in numeral modeling of the surfaces and introduction of new groups of tailored surfaces [2]. The appearance of new forms and types of thin-walled shell structures of this kind is inevitable. The bionic method of solving these tasks extends the limits of these opportunities [3]. Young architect Jose Pesantez from Catholic University of Cuenca has created two types of new forms of uncanonical bionic shell "YASUNI": a wooden rod structure covered with a tent and a cast-in-place concrete shell. This pavilion structure is planned to be erected in the city park of Cuenca (Ecuador).

\section{Description and calculation of shell}

The form of the shell imitates a leaf of a flower laying on the lay of the land. The triangular finiteelement mesh is created with a harmonic fusion of lily and daisy in a single structure (Fig. 1) [4].

Only stress-strain state of the cast-in-place concrete shell is investigated in this article.

Stress-strain state of the shell depends on the boundary conditions, with or without contour elements, the type of the external load - static, wind or seismic. The of finite elements analysis [5], implemented with the computer software SCAD [6], which allows to find out the regularity of the work of the building and take into consideration all the features of the structural concept, is used to define the reaction of the construction to the load and to estimate the most distinctive geometrical parameters of this shell. 
The overall view of the calculation model with the approximation of the middle surface by complex of flat triangle elements is shown in the figs. 2 and 3 [7].

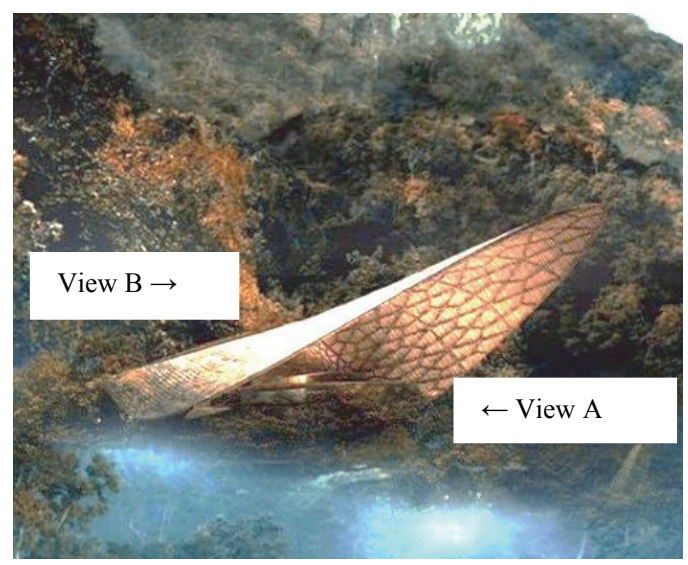

Figure 1. "YASUNI" shell

Geometrical overall dimensions of the scheme in the plan are $17.3 \times 5 \mathrm{~m}$, shell depth is $2.3 \mathrm{~m}$, fourpoint support with rigid fixing.

The size of the side of finite triangle elements is from $0.1 \mathrm{~m}$ to $0.4 \mathrm{~m}$. The number of the triangle elements is 3438 , joints 1813 . The shell is designed as a solid-cast one, made of different classes of reinforced concrete (B25, B30, B35) with thickness between $\delta=5 \mathrm{~cm}$ and $\delta=10 \mathrm{~cm}$ with a step $1 \mathrm{~cm}$ without contouring beams. The structure is estimated to withstand only its self-weight. Some of the results of analysis for a shell with thickness of $\delta=5 \mathrm{~cm}$, class of concrete B25 are listed in the figs. 4-7.

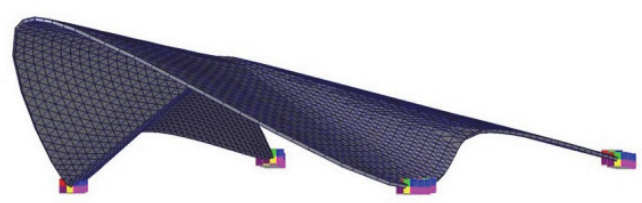

Figure 2. Design model. View A

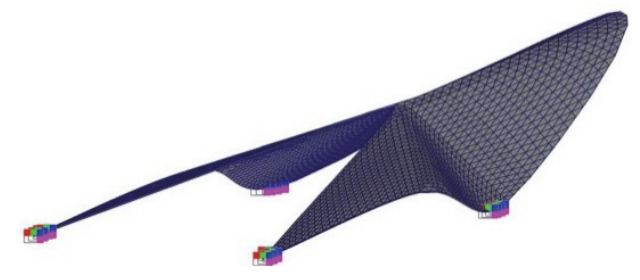

Figure 3. Design model. View B
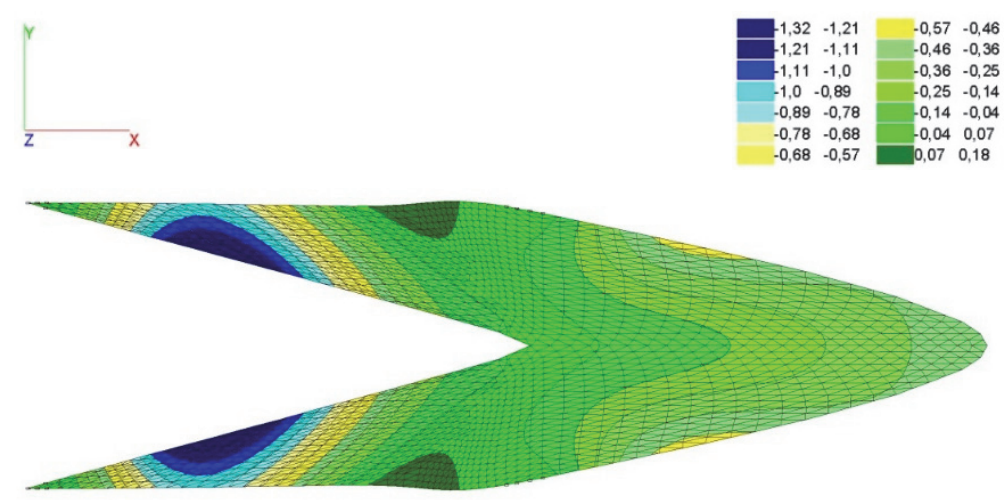

Figure 4. Vertical displacements (cm)

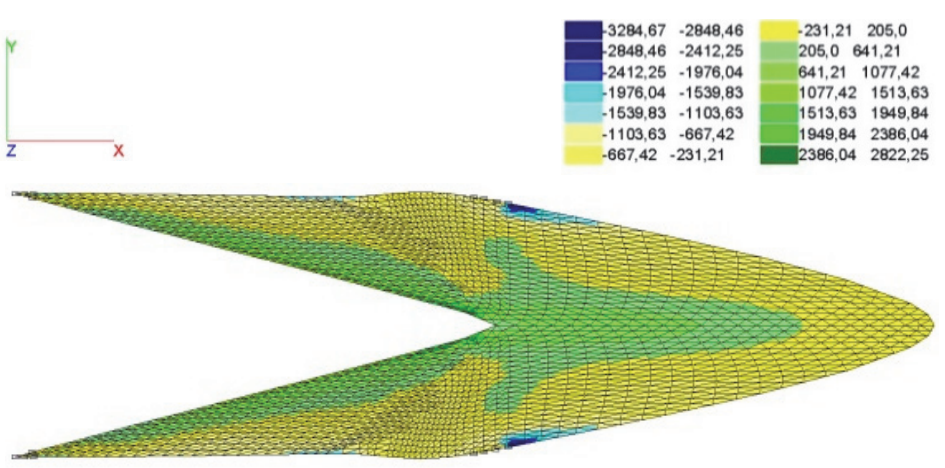

Figure 5. Normal stress $N_{x}\left(\mathrm{kN} / \mathrm{m}^{2}\right)$ 


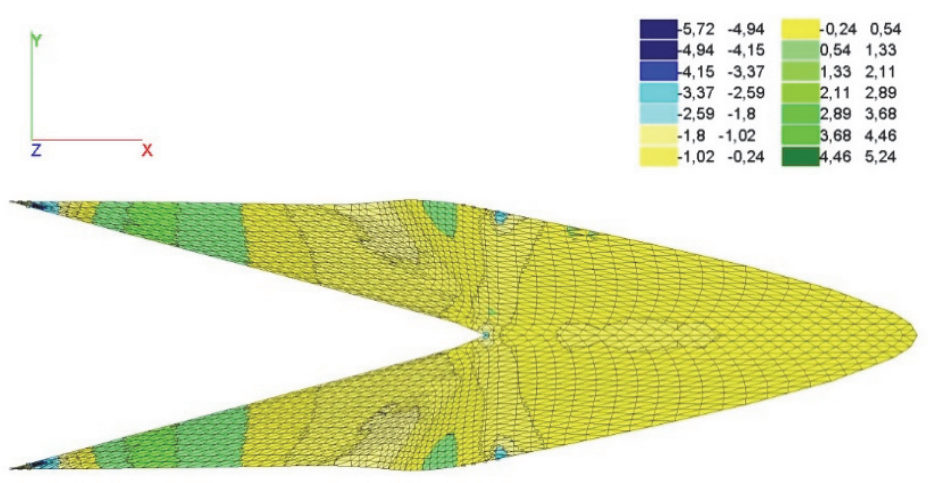

Figure 6. Bending moment $M_{x}(\mathrm{kNm} / \mathrm{m})$

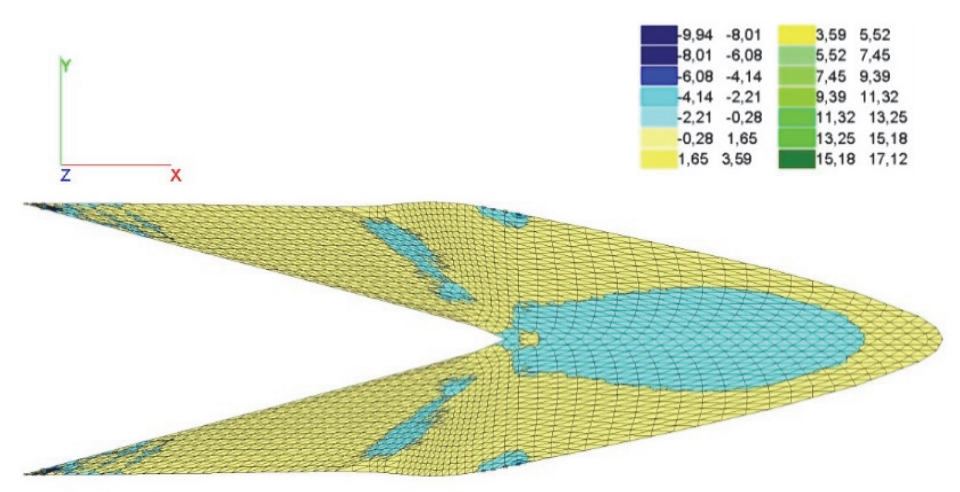

Figure 7. Bending moment $M_{y}(\mathrm{kNm} / \mathrm{m})$

The displacement of the console part of the shell is $5 \mathrm{~mm}$. The maximum displacement between the supports is $13 \mathrm{~mm}$. The isofields of bending moment $M_{x}$ shows that the shell works in the beam scheme in this direction. The rate of the maximum bending moment $M_{x}$ in the span between the supports is $2.1 \mathrm{kNm} / \mathrm{m}$. In the console part, the rate of bending moment $M_{x}$ ranges from $-0.24 \mathrm{kNm} / \mathrm{m}$ to $0.54 \mathrm{kNm} / \mathrm{m}$.

Maximum vertical displacements due to the shell self-weight are presented in the table 1 . The general pattern of distribution of isofields displacements for various thickness is analogous.

Table 1

\begin{tabular}{|c|c|c|c|}
\hline $\begin{array}{c}\text { Thick } \\
\text { ness } \boldsymbol{\delta} \\
(\mathbf{c m})\end{array}$ & $\begin{array}{c}\text { Max vertical } \\
\text { displacement } \\
\mathbf{( c m )} \text {, class of } \\
\text { concrete B25 }\end{array}$ & $\begin{array}{c}\text { Max vertical } \\
\text { displacement } \\
\mathbf{( c m )} \text {, class of } \\
\text { concrete B30 }\end{array}$ & $\begin{array}{c}\text { Max vertical } \\
\text { displacement } \\
\text { (cm), class of } \\
\text { concrete B35 }\end{array}$ \\
\hline 10 & $-0,42$ & $-0,39$ & $-0,37$ \\
\hline 9 & $-0,51$ & $-0,47$ & $-0,44$ \\
\hline 8 & $-0,62$ & $-0,57$ & $-0,53$ \\
\hline 7 & $-0,77$ & $-0,71$ & $-0,67$ \\
\hline 6 & $-0,99$ & $-0,91$ & $-0,86$ \\
\hline 5 & $-1,32$ & $-1,22$ & $-1,15$ \\
\hline
\end{tabular}

The value of normal stresses $N_{x}, N_{y}$, shear forces $Q_{x}, Q_{y}$, bending moments $M_{x}, M_{y}$ in the shell of the same thickness are similar for the different clas- ses of concrete. When the thickness of the shell made of specific class of concrete is increased, the normal stresses $N_{x}$ and $N_{y}$ decrease, the values shear forces $Q_{x}, Q_{y}$ and bending moments $M_{x}, M_{y}$ increase.

\section{Conclusion}

The article presents the first results of stressstrain state investigation of the "YASUNI" shell. The authors continue research on this shell with different geometrical parameters, the boundary conditions with the addition of contour elements. The computer software SCAD allows to reach the most advantageous technical-and-economic indexes of the investigated shell of complexed geometry.

(C) Olga O. Alyoshina, David Cajamarca Zuniga, 2018

(i) This work is licensed under a Creative Commons Attribution 4.0 International License

\section{References}

1. Krivoshapko S.N., Mamieva I.A. (2012). Vydayushchiesya prostranstvennye sooruzheniya poslednih 20 let [Outstanding wide-span spatial structures of last 20 years]. Montazhnye i special'nye raboty $v$ stroitel'stve [Installation and special works in construction], (12), 8-14. (In Russ.)

2. Krivoshapko S.N., Ivanov V.N. (2015). Encyclopedia of Analytical Surfaces. Springer International Publishing Switzerland, 752. 
3. Lebedev Y.S., Rabinovich V.I., Polozhay E.D., et al. (1990). Arhitekturnaya bionika [Architectural Bionics]. Moscow: Strojizdat Publ., 269. (In Russ.)

4. Doczi G. (2006). El poder de los límites: proporciones armónicas en la naturaleza, el arte y la arquitectura. Buenos Aires: Editorial Troquel.

5. Rozin L.A., Gordon L.A. (1971). Metod konechnyh ehlementov $\mathrm{v}$ teorii plastin i obolochek. [Finite element method in the theory of plates and shells]. Izvestiya $V N I I G$, (95), 85-97. (In Russ.)

6. Karpilovskij V.S., Kriksunov Eh.Z., Malyarenko A.A., Perel'muter A.V., Fialko S.Yu. (2015). SCAD Office. Versiya 21. Vychislitel'nyj kompleks SCAD++ [SCAD Office. Version 21. System SCAD++]. Moscow: SKAD SOFT Publ., 848. (In Russ.)

7. Larry J. Segerlind. (1984). Applied Finite Element Analysis. Second Edition. New York, John Wiley \& Sons.

About the authors

Olga O. Alyoshina - Civil Engineering Ph.D. student, Department of Civil Engineering, Engineering Academy,
Peoples' Friendship University of Russia (RUDN University). Scientific interests: theory of thin elastic shells, computer modeling, assessment of the stress-strain state. Contact: e-mail-xiaofeng@yandex.ru.

David Cajamarca Zuniga - Engineer, M.Sc., Associate Professor of the Department of Bridges and the Department of Structural Analysis, Catholic University of Cuenca. Scientific interests: large-span structures, bridges, high-strength and ultra-high-strength concrete, fiber-reinforced concrete, seismic resistance of structures, inspection and diagnostics of structures, analysis of strain-stress state of structures. Contact: e-mail cdavidcz@hotmail.com.

\section{For citation}

Alyoshina O.O., Cajamarca Zuniga D. (2018). Stressstrain state investigation of the "YASUNI" shell by bionic architecture methods based on numerical modeling. Structural Mechanics of Engineering Constructions and Buildings, 14(4), 273-277. DOI: 10.22363/1815-5235-2018-144-273-277.

\title{
Исследование напряженно-деформированного состояния оболочки «YASUNI» методами бионической архитектуры на основе численного моделирования
}

\author{
О.О. Алёшина ${ }^{1}$, Д. Кахамарка-Сунига ${ }^{2 *}$ \\ ${ }^{1}$ Российский университет дружбы народов \\ ул. Миклухо-Маклая, 6, Москва, Российская Федераџия, 117198 \\ ${ }^{2}$ Католический университет г. Куэнки \\ Ав. Дон Боско, 288, Куэнка, Эквадор, 0101114 \\ *Автор, ответственный за переписку
}

(поступила в редакичию: 04 мая 2018 г.; принята к публикацчии: 26 июля 2018 г.)

\begin{abstract}
Архитектуру и строительство сложно представить без большепролетных оболочек различного назначения и, учитывая запросы архитекторов, новые достижения в численном моделировании поверхностей, введение в обращение новых групп поверхностей, обладающих определенными заданными свойствами, появление новых форм и видов тонкостенных конструкций такого типа неизбежно. Бионический подход к решению этих задач расширяет границы данных возможностей. В статье исследуется напряженно-деформированное состояние новой неканонической оболочки «YASUNI», проектируемой из монолитного железобетона с применением современной расчетной системы конечно-элементного анализа конструкций. Форма оболочки составлена на основе образов представителей местной флоры Эквадора. Форма оболочки имитирует лист цветка, лежащего на рельефе местности. Треугольная конечно-элементная сетка создана путем гармоничного объединения формы листьев лилии и маргаритки в единую конструкцию. Оболочка проектируется монолитной из различных классов железобетона (B25, В30, В35) толщиной от $\delta=5$ см до $\delta=10$ см с шагом 1 см без контурных балок. Конструкция рассчитывается на восприятие равномерно-распределенного собственного веса. Приводятся первые результаты исследования напряженно-деформированного состояния оболочки «YASUNI». Авторы продолжают изучение работы данной оболочки при различных геометрических параметрах, граничных условиях с добавлением контурных элементов. Благодаря вычислительному комплексу SCAD OFFICE, обладающему достаточной точностью для выполнения расчетов, можно добиться наиболее выгодных технико-экономических показателей рассматриваемой неканонической оболочки.
\end{abstract}

Ключевые слова: оболочка неканонической формы, бионическая архитектура, метод конечного элемента, треугольная конечно-элементная сетка, напряженно-деформированное состояние, монолитная железобетонная конструкция, вычислительный комплекс SCAD Office 


\section{Список литературы}

1. Кривошапко С.Н., Мамиева И.А. Выдающиеся пространственные сооружения последних 20 лет // Монтажные и специальные работы в строительстве. 2012. № 12. C. 8-14.

2. Krivoshapko S.N., Ivanov V.N. Encyclopedia of Analytical Surfaces. Switzerland: Springer International Publishing, 2015. $752 \mathrm{p}$.

3. Лебедев Ю.С., Рабинович В.И., Положай Е.Д. и др. Архитектурная бионика / под ред. Ю.С. Лебедева. М.: Стройиздат, 1990. 269 с.

4. Doczi G. El poder de los límites: proporciones armónicas en la naturaleza, el arte y la arquitectura. Buenos Aires: Editorial Troquel, 2006.

5. Розин Л.А., Гордон Л.А. Метод конечных элементов в теории пластин и оболочек // Известия ВНИИГ. 1971. Вып. 95.

6. Карпиловский В.С., Криксунов Э.3., Маляренко А.А., Перельмутер А.В., Фиалко С.Ю. SCAD Office. Версия 21. Вычислительный комплекс SCAD++. М.: СКАД СОФТ, 2015. 848 с

7. Larry J. Segerlind. Applied Finite Element Analysis. Second Edition. New York: John Wiley \& Sons, 1984.

\section{Об авторах}

Алёшина Ольга Олеговна - аспирант департамента строительства Инженерной академии, Российский университет дружбы народов. Область научных интересов: теория тонких упругих оболочек, компьютерное моделирование, оценка напряженно-деформированного состояния конструкций и сооружений. Контактная информация: e-mail - xiaofeng@yandex.ru.

Давид Кахамарка-Сунига - доцент кафедры мостов и кафедры строительных конструкций и сооружений, Католический университет г. Куэнки. Область научных интересов: большепролетные строительные сооружения, мосты, высокопрочный и ультравысокопрочный бетон, фибробетон, сейсмостойкость сооружений, обследование и диагностика сооружений, оценка напряженно-деформированного состояния строительных конструкций и сооружений. Контактная информация: e-mail-cdavidcz@hotmail.com.

\section{Для цитирования}

Alyoshina O.O., Cajamarca Zuniga D. Stress-strain state investigation of the "YASUNI» shell by bionic architecture methods based on numerical modeling // Строительная механика инженерных конструкций и сооружений. 2018. Т. 14. № 4. C. 273-277. DOI: 10.22363/ 1815-5235-2018-14-4-273-277. 